\title{
International Committee on Systematic Bacteriology Subcommittee on the Taxonomy of Mollicutes
}

\author{
Minutes of the Interim Meeting, 12 and 18 July 1996, Orlando, Florida, U.S.A.
}

\section{Session 1. Closed meeting.}

Minute 1. Call to order. The closed meeting was called to order at 9:00 a.m. on 12 July 1996 by the Chair, R. F. Whitcomb, who thanked M. B. Brown, M. K. Davidson, and J. K. Davis, the organizers of the 12th International Congress of the International Organization for Mycoplasmology (IOM), for their assistance in making arrangements for the subcommittee meetings.

Minute 2. Record of attendance. The members present were J. M. Bové, J. M. Bradbury (Secretary), G. Christiansen, K.-E. Johansson, I. Kahane, B. C. Kirkpatrick, F. Laigret, R. J. Miles, J. D. Pollack, S. Razin, D. Taylor-Robinson, and J. G. Tully. D. Pitcher (advisory member) and J. A. Robertson, Chair of the Board of the IOM International Research Programme on Comparative Mycoplasmology (IRPCM), were in attendance. Also present by invitation were J. K. Davis and M. K. Davidson of the University of Florida. Apologies for absence were received from E. A. Freundt, R. H. Leach, J. Maniloff, and H. C. Neimark. The subcommittee received with regret the resignations of B. B. Sears, C. J. Morrow, and E. A. ter Laak.

Minute 3. Report of the Chair. R. F. Whitcomb acknowledged the considerable input of J. G. Tully into subcommittee business and mollicute taxonomy in general. In reporting that the U.S. Department of Agriculture has discontinued spiroplasma research, he announced his resignation from the Chair. Subcommittee activities since the previous meeting in Bordeaux, France (Int. J. Syst. Bacteriol. 45:415-417, 1995), were reviewed. New species in the class Mollicutes described since the last interim meeting include four Mycoplasma species (Mycoplasma adleri, Mycoplasma crocodyli, Mycoplasma elephantis, and Mycoplasma sturni) and six Spiroplasma species (Spiroplasma corruscae, Spiroplasma diabroticae, Spiroplasma diminutum, Spiroplasma ixodetis, Spiroplasma syrphidicola, and Spiroplasma velocicrescens). Members of the IRPCM Spiroplasma Working Team have collaborated to complete the characterization of 10 more species. A Candidatus species, Phytoplasma aurantifolia, has been proposed for the witches'-broom phytoplasma.

Minute 4. Recent developments in the taxonomy of mollicutes. J. G. Tully reported on a rule (to replace Recommendation $30 \mathrm{a}$ in the International Code of Nomenclature of Bacteria) which requires type strains of new cultivable bacterial species to be deposited in a permanent culture collection before the name is published (R. G. E. Murray, Int. J. Syst. Bacteriol. 46:831, 1996). Furthermore, if the type strain has a patent, then publication will be deferred until the patent has cleared. The subcommittee recommended further clarification of the taxonomic status of Mycoplasma feliminutum and Acholeplasma multilocale since both of these taxa appear to have properties inconsistent with their genus assignments (D. R. Brown et al., Int. J. Syst. Bacteriol. 45:560-564, 1995; J. D. Pollack et al., Int. J. Syst. Bacteriol. 46:885-890, 1996)

Minute 5. 16S rDNA sequence analysis in mollicute taxonomy. The subcommittee reaffirmed its position, as stated in the revised minimum standards document for the description of new species of mollicutes (R. F. Whitcomb et al., Int. J. Syst. Bacteriol. 45:605-612, 1995), on the importance of $16 \mathrm{~S}$ ribosomal DNA (rDNA) sequence analysis in classification. Future revisions of the document will include a recommendation that such data be sought as part of minimum standards, but in the interim the subcommittee strongly urged that descriptions of new species should contain this information. Problems associated with deposition of mollicute $16 \mathrm{~S}$ rDNA sequences in the GenBank database were discussed. Sequences are currently available for only about one-half of the validly described $M y$ coplasma species, so it would be unsound to name a new species solely on the basis of comparison with this limited database. Nevertheless, illegitimate names have been used for GenBank depositions (e.g., "Mycoplasma agassizii" and "Mycoplasma volis") and have appeared subsequently in the literature without valid publication. The subcommittee placed great emphasis on obtaining full-length $16 \mathrm{~S}$ rDNA sequence data for representatives of as many existing taxa as possible, including especially phenotypically unusual organisms or species that pose taxonomic quandaries. It was agreed that GenBank should be informed of the potential taxonomic problems created by illegitimate names.

Minute 6. Spiroplasma reclassification. P. Carle, J. M. Bové, and their colleagues have established the genome sizes and $\mathrm{G}+\mathrm{C}$ contents of 46 spiroplasma species, putative species, or strains. The genome sizes range from 780 to $2,220 \mathrm{kbp}$, confirming that the range is too broad to be of use in differentiating higher taxa (J. G. Tully et al., Int. J. Syst. Bacteriol. 43:378-385, 1993). It was thought that the spiroplasmas with smaller genomes might have lost the ability to grow well and produce helical morphology. This does not appear to be true since some of the organisms with the smallest genomes still grow rapidly and maintain their helical morphology, while some organisms with large genomes are very slow growing. Approximately 10 new species are in the process of description, another eight spiroplasma groups (groups XXVI to XXXIII) will be added to the classification (D. L. Williamson et al., unpublished data), and vacant group XVII will be filled (C. Helias et al., unpublished data). R. F. Whitcomb described many one-way serological cross-reactions that occur among the tabanid spiroplasmas in deformation and metabolism inhibition tests. These reactions cause serious problems in classification and identification.

Minute 7. Update on phytoplasma classification. B. C. Kirkpatrick reported that the genus name Phytoplasma appears to have been almost universally adopted in the literature. The IRPCM Phytoplasma Working Team agreed that the major clades emerging from analysis of full-length sequences of the $16 \mathrm{~S}$ rRNA gene should represent Candidatus species of the genus. Thus, approximately 14 groups are known, although so far only one name, Candidatus Phytoplasma aurantifolia, has been published (L. Zreik et al., Int. J. Syst. Bacteriol. 45:449 $453,1995)$. B. C. Kirkpatrick is writing general guidelines for the genus description, and the current priority is to publish the other Candidatus species descriptions. The subcommittee confirmed that the proposals by R. G. E. Murray and K. H. Schleifer (Int. J. Syst. Bacteriol. 44:174-176, 1994), in which nucleotide sequence analysis and identification of morphotypes are the basis of descriptions, should be followed for descriptions of new phytoplasma Candidatus species. The new classification based on 16S rRNA gene sequences should replace the con- 
fusing historical classifications. Several subcommittee members were aware that a proposal had been submitted to the International Journal of Systematic Bacteriology for a Phytoplasma subspecies designation under the Candidatus concept. However, the manuscript was not accepted, and an editorial statement indicated that the Candidatus description was intended only to cover descriptions to the species level. After further discussion the subcommittee agreed that it would be inappropriate to use subspecies classification until the Candidatus species had been described. This would not preclude the development of informal subgroups. With the present knowledge it was difficult to define suitable criteria for classifying phytoplasmas at the subspecies level, but any technique(s) adopted should be widely available. It was felt that restriction fragment length polymorphism analysis of $16 \mathrm{~S}$ rRNA sequences was not suitable since too few nucleotides are compared by this procedure. Furthermore, the level of difference in $16 \mathrm{~S}$ rDNA sequences necessary to define a subspecies cannot be defined yet. Information on other gene sequences and biological properties, such as "pathovars," might be needed to extend the classification. Subcommittee members and others are encouraged to identify conserved genes that might be used in addition to the $16 \mathrm{~S}$ rRNA gene for building a classification. J. M. Bové cautioned that some healthy plants and insects may give a signal in PCR tests when primers for the $16 \mathrm{~S}$ rRNA gene are used because plant chloroplasts and mitochondria have $16 \mathrm{~S}$ rRNA genes which are similar to the corresponding genes of bacteria. Other workers have not encountered this problem.

Minute 8. Taxonomic status of the Mycoplasma mycoides cluster. K.-E. Johansson reminded the subcommittee that members of the $M$. mycoides cluster have two 16S rRNA genes originating from the two rRNA operons and that there are sequence differences (polymorphisms) between the two genes. Phylogenetic trees derived from $16 \mathrm{~S}$ rRNA data from the two operons divide all of the organisms into two subclusters (B. Pettersson et al., J. Bacteriol. 178:4131-4142, 1996), with the exception of the $M$. mycoides subsp. mycoides small-colony type, which falls between the two groups. The data also show that the large-colony type is more closely related to $M$. mycoides subsp. capri and that strain PG50 (bovine group 7) is very closely related to Mycoplasma capricolum subsp. capricolum. It was agreed that the rRNA genes of selected strains of this bovine serogroup should be sequenced to help clarify its taxonomic status. The sequence data also show that $M$. capricolum subsp. capripneumoniae (the causal agent of contagious caprine pleuropneumonia), while closely related to $M$. capricolum subsp. capricolum, is different in having an unusually large number of polymorphisms. A possible reclassification of the subspecies was discussed in light of these observations, although DNA-DNA hybridization between the organisms gives a level of relatedness of about $70 \%$ at high stringency $(\mathrm{F}$. Bonnet et al., Int. J. Syst. Bacteriol. 43:597-602, 1993). Consideration was also given to removal of the members of the $M$. mycoides cluster from the genus Mycoplasma due to their closer phylogenetic relationship to the genus Spiroplasma. However, such a reclassification would create considerable problems in diagnostic veterinary medicine and legislature in many countries. Likewise, reassignment of all other Mycoplasma species to a new genus would have unacceptable consequences in human and veterinary medicine. For the time being a polyphasic classification which is based only partly on phylogeny and which is a compromise containing a minimum of contradictions will probably be used (P. Vandamme et al., Microbiol. Rev. 60:407-438, 1996). The binomial classification may never reflect the phylogenetic classification, but the sub- committee has made considerable efforts to fit mollicute taxa into the phylogenetic classification. S. Razin urged caution in reclassifying the mollicutes by phylogeny based almost exclusively on $16 \mathrm{~S}$ rRNA sequences. In a few years a much broader genetic basis will be available and may give a different picture. After much debate an ad hoc committee consisting of K.-E. Johansson (Chair), R. H. Leach, R. J. Miles, S. Razin, and J. G. Tully was established to discuss the complex issues relating to the $M$. mycoides cluster and to prepare a proposal for resolving the taxonomic status of the group. This proposal will be circulated to members of the subcommittee before the next interim meeting.

Minute 9. Ureaplasma urealyticum. J. A. Robertson reported that relationships among the named Ureaplasma species have been clarified (R. Harasawa and G. H. Cassell, Int. J. Syst. Bacteriol. 46:827-829, 1996; G. W. Stemke and J. A. Robertson, Int. J. Syst. Bacteriol. 46:1183-1184, 1996). Stemke and Robertson showed that Ureaplasma gallorale is more closely related to the human ureaplasmas than to the other named species, which are found in domesticated animals. A publication differentiating the two $U$. urealyticum biovars into $U$. urealyticum and Ureaplasma parvum will be submitted soon. Studies on the biovars with regard to human health have proved to be difficult due to the extra work involved in biotyping and the lack of interest by clinicians, but so far all clinical isolates which have been biotyped fit into one of the two biovars.

Minute 10. Possible implications of antigenic variation. The subcommittee discussed a recent paper describing antigenic variation in Mycoplasma species and the possible implications for species identification and strain standardization (R. Rosengarten and D. Yogev, J. Clin. Microbiol. 34:149-158, 1996). In this paper the authors express surprise that the subcommittee failed to recommend avoiding cloning of already defined type strains in the revised minimum standards document. Subcommittee members with experience in mollicute identification agreed that a degree of antigenic variation has long been recognized in some species but that it does not present serious difficulties in identification as long as polyclonal antibodies are used. For purposes of classification cloning is essential because original isolates may contain more than one species. The subcommittee agreed that some precautionary statement should be made in the next revision of the minimum standards document with regard to the use of monoclonal antibodies in diagnostic testing and to concerns of the relationship between cloning and antigenic variation within certain species.

Minute 11. Minimum standards document. J. G. Tully reported that the revised minimum standards for the description of new species of mollicutes (Subcommittee on the Taxonomy of Mollicutes, Int. J. Syst. Bacteriol. 45:605-612, 1995) had been well received and that an abstracted version could be found in a new methods book (J. G. Tully and R. F. Whitcomb, p. 339-347, in S. Razin and J. G. Tully, ed., Molecular and Diagnostic Procedures in Mycoplasmology, vol. I, Academic Press, San Diego, Calif., 1995.). As stated in Minute 5, the next revision should recommend the inclusion of 16S rRNA gene sequence data as part of the minimum standards for the description of mollicute species.

Minute 12. Mollicute genome sequencing. The subcommittee again emphasized the need to obtain complete 16S rDNA sequences for the numerous mollicutes not examined so far. Many laboratories now have relatively inexpensive sequencing services, and some have a sequence alignment facility. The Ribosomal Database Project (RDP) will prepare phylogenetic trees for data transmitted via the Internet. An electronic version of Bergey's Manual of Systematic Bacteriology is in preparation. Some attempt will be made to correlate phylogenetic 
relationships within current classifications by using information in the RDP and GenBank databases. There are obvious disagreements between some RDP designations for names of higher taxa within specific groups of bacteria, especially within the mollicutes. The subcommittee was concerned that some assignments made in the current RDP list of phylogenetic relationships among mollicutes were incorrect, particularly where certain species that had clearly not had sequence data collected were assigned arbitrarily to established clades. Likewise, the revised classification of the class Mollicutes published in 1993 (J. G. Tully et al., Int. J. Syst. Bacteriol. 43:378-385), in which the authors made a serious attempt to correlate phylogenetic relationships within the higher taxa, was completely ignored in the RDP listing. R. F. Whitcomb and J. G. Tully agreed to submit a draft of the current understanding of the phylogenetic relationships of various members of the class Mollicutes to both the RDP and the subcommittee. When sequences are submitted to GenBank, it is important that the term "mollicute" is included in the description.

Minute 13. Liaison with the IRPCM. The status of the international collaborative working teams was reviewed by the IRPCM Chair, J. A. Robertson. Some teams have been decimated by retirements and funding problems, and the teams concerned with the mollicutes of mammals require revision. The Mollicute Detection Working Team needs to be activated in the next biennium, particularly because of renewed awareness of contaminated cell lines, such as those used in human immunodeficiency virus studies. It was hoped that this team could evaluate and make recommendations on evolving diagnostic methods. J. M. Bové pointed out that Hoffmann-La Roche has a patent on PCRs based on rRNA for mollicute detection. Unless this patent has been purchased, the technique should be used only for research. J. D. Pollack suggested that a liaison might be established between the IRPCM Ruminant Mycoplasmas Working Team and the COST (European Co-operation in the Field of Scientific and Technical Research) group on ruminants' mycoplasmoses in order to promote their mutual interests.

Minute 14. Status of NIAID and NCTC mollicute reference strain and antiserum collections. The transfer of strains and antisera from the National Institute of Allergy and Infectious Diseases (NIAID), Frederick, Md., to the University of Florida remains to be officially ratified by the legal departments of the two organizations. J. G. Tully reported that attempts to obtain "seed" funds from the National Institutes of Health for preparation of antisera had been unsuccessful. A computer database containing culture histories is almost complete. The University of Florida hopes to provide reagents to bona fide researchers on a nonprofit basis and to obtain funds to expand the antiserum collection. J. D. Pollack volunteered a collection of antisera and/or strains that had been given to him, and a substantial part of R. F. Whitcomb's reagents will also be donated. D. Pitcher summarized the situation at the Mycoplasma Reference Unit (MRU), London, England. As a result of a recent review, the MRU has been transferred from the National Collection of Type Cultures (NCTC) to a new Atypical Pneumonias Unit but remains at the same address. In the future the unit will deal only with research and diagnosis related to public health matters, and this means that there will be no work on animal mycoplasmas. Because of this the designation as a World Health Organization/Food and Agriculture Organization Collaborating Centre was not renewed at the end of the contract in July 1994. D. Pitcher remains the leader of the research and reference activities. The NCTC will continue to supply mycoplasma cultures and antisera as before, including reagents inherited from the University of Aarhus. In addi- tion, antisera from several other inherited collections are available. Although there is currently no provision for the production of antisera when stocks are depleted, every effort will be made to assist applicants in obtaining the antisera that they request. Unlike the American Type Culture Collection, the NCTC is a reference collection for bacteria of medical and veterinary significance and will continue to accession mycoplasma species which fall into this category. Requests for accessioning of other mycoplasmas should be directed elsewhere. In the United Kingdom separate culture collections exist for plant and other bacteria.

Minute 15. Future meeting schedule. The next interim meeting of the subcommittee will take place in association with the 12th International Congress of the IOM in Sydney, Australia (23 to 29 July 1998). Tentative plans also call for an interim meeting during the 13th IOM Congress in Fukuoka, Japan, in 2000 .

Minute 16. Election of officers and membership changes. Following the formal retirement of the Chair, J. M. Bradbury and K.-E. Johansson were nominated and elected as new Chair and Secretary, respectively. It was agreed that these positions would have 4-year terms of office. It was agreed by ballot that R. H. Leach and D. Taylor-Robinson will become advisory members. J. Frey, G. Firrao, J. A. Robertson, R. F. Rosenbusch, and K. Sachse were elected as new members, and D. Pitcher, J. K. Davis, and M. K. Davidson are now ex officio members. C. Minion is also an ex officio member as the new Chair of the Board of the IOM IRPCM.

Minute 17. Adjournment. The meeting was adjourned at 5:45 p.m.

\section{Session 2. Open meeting.}

Minute 18. Call to order. An open meeting of the subcommittee was called to order at 10:30 a.m. on 18 July 1996.

Minute 19. Record of attendance. The members present were R. F. Whitcomb (Chair), J. M. Bradbury (Secretary), J. M. Bové, G. Christiansen, K.-E. Johansson, F. Laigret, H. C. Neimark, J. D. Pollack, D. Taylor-Robinson, and J. G. Tully; J. A. Robertson, D. Pitcher, J. K. Davis, and M. K. Davidson also attended.

Minute 20. Report of the Chair. R. F. Whitcomb, in welcoming approximately 80 attendees to the meeting, stated that the subcommittee wished to receive opinions and comments on aspects of the classification of Mollicutes.

Minute 21. Spiroplasma reclassification. R. F. Whitcomb outlined the changes occurring in the classification of the genus Spiroplasma. He mentioned that six new species had been described, that 10 more are expected in the near future, and that eight new groups have been added to the genus.

Minute 22. Other new species of Mollicutes. J. G. Tully reported that four new Mycoplasma species had been described during the last biennium and that a Candidatus species of phytoplasma has been described. He emphasized that it was not acceptable to name new species solely on the basis of a comparison with the $16 \mathrm{~S}$ rDNA sequences currently available. Attempts will be made to obtain sequence data for the many remaining species so that comparisons will be more meaningful and so that future revisions of the minimum standards document can strongly recommend that sequence data be included in the descriptions of new species.

Minute 23. Classification of the phytoplasmas. J. M. Bové stressed the importance of $16 \mathrm{~S}$ rDNA sequencing for the classification of phytoplasmas. He confirmed that the subcommittee was against the establishment of subspecies status in the genus, at least until the Candidatus species have been established. Thus, the immediate priority is to publish descriptions of the remaining 13 Candidatus species. 
Minute 24. Taxonomic status of the M. Mycoides cluster. K.-E. Johansson described the difficulties created by the close relationships of members of the $M$. mycoides cluster and by the phylogenetic distance of this cluster from other members of the genus Mycoplasma. The subcommittee had decided that taxonomic reassignments of genera were inappropriate in light of present knowledge and particularly in view of the profound implications for veterinary medicine and legislature. A working group was established under the chairmanship of K.-E. Johansson to examine in detail the taxonomic problems within the $M$. mycoides cluster.

Minute 25. $U$. urealyticum. J. A. Robertson reported that the two biotypes of $U$. urealyticum will soon be divided into two species. The name $U$. parvum will be proposed for the second biotype.

Minute 26. Status of the mollicute reference collections. J. G. Tully and D. Pitcher summarized the positions of collections at NIAID, Frederick, Md., and the former MRU, London, United Kingdom, respectively. The transfer of the NIAID collection to the University of Florida is proceeding. Despite some downsizing, the London collection is still open to requests for reagents from research workers and hopes to expand again under new budgetary arrangements.

Minute 27. Resignation of the Chair. R. F. Whitcomb announced his resignation as Chair of the subcommittee. J. M. Bové, on behalf of the subcommittee and of mycoplasmolo- gists in general, thanked him for his untiring interest and efforts in mollicute taxonomy for more than 20 years. His skills in achieving cooperation and consensus among subcommittee members on many contentious issues were greatly appreciated.

Minute 28. Adjournment. The open meeting adjourned at 11:30 p.m. on 18 July 1996.

Minute 29. Current membership. The current membership of the subcommittee is as follows: J. M. Bradbury, Liverpool, United Kingdom (Chair Elect); K.-E. Johansson, Uppsala, Sweden (Secretary Elect): J. M. Bové, Bordeaux, France; G. Christiansen, Aarhus, Denmark; J. Frey, Bern, Switzerland; G. Firrao, Udine, Italy; I. Kahane, Jerusalem, Israel; B. C. Kirkpatrick, Davis, Calif.; F. Laigret, Bordeaux, France; R. J. Miles, London, United Kingdom; H. C. Neimark, Brooklyn, N.Y.; J. D. Pollack, Columbus, Ohio; S. Razin, Jerusalem, Israel; J. A. Robertson, Edmonton, Canada; R. F. Rosenbusch, Ames, Iowa; K. Sachse, Jena, Germany; J. G. Tully, Frederick, Md.; and R. F. Whitcomb, Beltsville, Md. Advisory members are E. A. Freundt, Aarhus, Denmark; R. H. Leach, London, United Kingdom; and D. Taylor-Robinson, London, United Kingdom. Ex officio members are F. C. Minion, Ames, Iowa, (IOM IRPCM Chair); J. K. Davis and M. K. Davidson, Gainesville, Fla.; and D. Pitcher, London, United Kingdom.

J. M. Bradbury, Past Secretary 